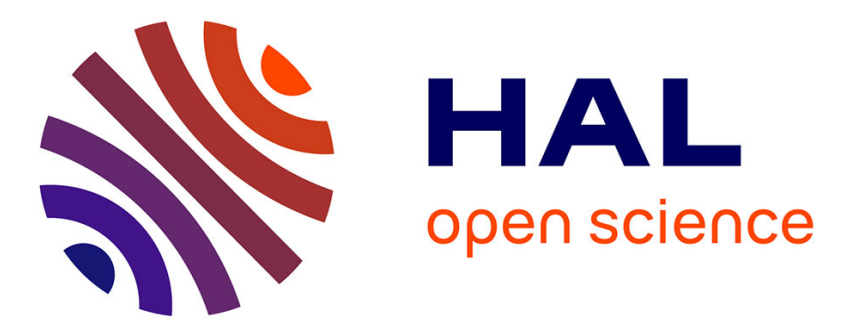

\title{
Reindeer feeding ecology and hunting strategies by Magdalenians from Pincevent (Paris Basin, France): New insights from dental microwear textural analyses
}

Natacha Catz, Olivier Bignon-Lau, Gildas Merceron

\section{- To cite this version:}

Natacha Catz, Olivier Bignon-Lau, Gildas Merceron. Reindeer feeding ecology and hunting strategies by Magdalenians from Pincevent (Paris Basin, France): New insights from dental microwear textural analyses. International Journal of Osteoarchaeology, 2020, 30 (4), pp.519-528. 10.1002/oa.2879 . hal-03435141

\author{
HAL Id: hal-03435141 \\ https://hal.science/hal-03435141
}

Submitted on 30 Nov 2021

HAL is a multi-disciplinary open access archive for the deposit and dissemination of scientific research documents, whether they are published or not. The documents may come from teaching and research institutions in France or abroad, or from public or private research centers.
L'archive ouverte pluridisciplinaire HAL, est destinée au dépôt et à la diffusion de documents scientifiques de niveau recherche, publiés ou non, émanant des établissements d'enseignement et de recherche français ou étrangers, des laboratoires publics ou privés. 
1 Title: Reindeer Feeding ecology and Hunting strategies by Magdalenians from Pincevent strategic behavior among hunters. France.

Abstract:

${ }^{1}$ ArScAn UMR 7041, Equipe Ethnologie préhistorique - Université de Paris 1 Panthéon-Sorbonne,

${ }^{2}$ Palevoprim UMR 7262 (CNRS \& Université de Poitiers), 86073 Poitiers Cedex 9, France.

In Pincevent (Paris Basin), archeaozoologists have observed a variation of hunting strategies between Magdalenian levels IV0 and IV20. Previous works on human-prey interaction showed that hunters modeled their behavior on their prey; therefore, reconstructing animal behavior in order to reconstruct human strategies could enable better interpretation of these levels. This study aims to contribute to a global understanding of the variation between these level's hunting strategies using microwear texture analysis. This proxy, which can be used to reconstruct diet, will enable to detect changes in the behavior pattern of the prey. The decision was made to focus this study on reindeer (Rangifer tarandus) as it was one of the two most exploited resources on this site, alongside horses. The enamel surface of teeth from two populations of reindeer, hunted and found in levels IVO and IV20, showed a variation of diet between levels. Environmental and ecological matters are discussed with an aim to understanding this variation of behavior in reindeer populations and highlight a change of Analyses, Animal exploitation. 


\section{1- INTRODUCTION}

The Paris Basin is a privileged region to study Magdalenian societies at the end of the Paleolithic period (Late Glacial, 13,000-12,000 years BP; Figure 1A and Table 1). Among the sites of this region, Pincevent occupation floors are a reference for exploring variations over a very short time period due to its well-preserved stratigraphic sequence, resulting from several overflows of silt or sandy silt from the Seine deposits (Figure 1b; Orliac 2006, 2014). Based on archeological remains, paleo-ethnology studies were developed in Pincevent to study Magdalenian occupations and reconstruct their way of life, their activities and their social organization, all of which were linked to their subsistence strategies (Leroi-Gourhan \& Brézillon, 1966; 1972; Julien \& Karlin, 2014). The huge number of faunal remains from reindeer (Rangifer tarandus) and horses (Equus caballus arcelini s.l., Bignon et al., 2006), in almost every level at Pincevent, and in many other sites of the region, indicates that the Magdalenian economy was based on these two key prey (David, 1994; Enloe, 1998; Bignon, 2008; David et al., 2014). This research underlines a coevolutive link between prey-species and prehistoric hunters during the Late Glacial in the Paris Basin (Bignon-Lau, 2014). Dental microwear texture analysis was applied to assess the dietary spectrum of Pincevent's reindeer, in order to support hunting strategy changes and, most notably, the season in which reindeer were most often slaughtered. As a ruminant, extant reindeer are selective while their feeding behavior shows a relative plasticity. And they are described as regional mixed feeder whose food component varies spatially and seasonally (LeaderWilliams, 1988; Skogland, 1984, 1989; Syroechkovskii, 1995; Semprebon and Solounias, 2002; Danell et al., 2006): from lichen consumption throughout the year to other resources depending on their availability in the environment (reconstructed by stomach content studies 2 ; Kuntz, 2011). During mastication, food items wear dental enamel, resulting in the so-called 
dental microwear. When the animal dies, the dental microwear allows us to assess the food properties of the animal from its last few days or weeks (Teaford et al, 1989a, 2017). When applied to vegetarian species, diet mirrors vegetal resource availability, which highlights habitat condition (Merceron et al., 2010).

Applied to a large range of species in the last 15 years, Dental microwear textural analysis (Scott et al. 2005, Merceron et al. 2016, 2018) aims to assess differences in dietary habits between inter- and intra-population scales (Percher et al. 2017; Berlioz et al. 2018; Scott, 2012). Here, the method is applied on the archeological dental material from the two levels excavated at Pincevent: level IV0 and level IV20. Each level is interpreted to characterize a very distinctive faunal spectrum (Bignon et al., 2006; Bignon, 2008; David et al., 2014; Bignon-Lau, 2014; Debout et al., 2012): level IV20 represents a massive reindeer killing in a single season (fall), whereas the level IV0 assemblages represent an association of reindeer and horses hunted and killed over a period of approximatively a year.

With this paper, our main goal is to use this very rich and complex archaeological grounds of these two exceptional preserved Magdalenian levels of Pincevent to show how DMTA can bring relevant data highlighting both reindeer behavior and hunting strategies. Two populations of present-day reindeer, with a total of 102 individuals living under different habitat conditions in Norway, were used as comparative baselines (alpine tundra reindeer; Bignon-Lau et al., 2017).

\section{2- ARCHEOLOGICAL CONTEXTS}

\section{1 - Magdalenian of the Paris Basin}

The Late Magdalenian (13,300-11,950 cal BC, Valentin, 2008; Debout et al., 2011) is currently the best-known period of the Pleistocene in the Paris Basin, with more than over forty known sites. Most of these are highly concentrated in the south of Paris, in the Seine 
Valley, with fewer settlement expansions in the northern and western zones of the region (Figure 1a). Magdalenian sites provide some well-preserved occupations where the remains are almost unaltered and found in their original position. For instance, the open-air sites of Etiolles, Pincevent, Verberie and the sites of the Seine-Yonne confluence are stratified with between five and fifteen occupation levels. These occupations are separated by thin deposits of alluvia which have rapidly piled up due to the annual overflows of the River Seine. The formation of these sequences is estimated to have occurred over a few generations, during an instable climatic period, but it seems that the same individuals came back repeatedly (Bodu 2010; Julien and Karlin 2002; Rodriguez and Roblin-Jouve 2004). The successive return visits to the same place confirm the regularity of displacements and allow functional variability of the occupations within the same site to be studied. The environment around the sites has been studied at sites such as Pincevent, Tureau-des-Gardes, Verberie, Etiolles, providing wellpreserved fauna remains.

The Magdalenian sites were studied using the paleo-ethnographic approach elaborated by André Leroi-Gourhan at Pincevent (Leroi-Gourhan and Brézillon 1966, 1972; see Supplementary Information for details).

\section{2 - Pincevent}

Pincevent is an open-air site located in the middle Seine valley which offers very well preserved archeological levels (Figure 1b). Among the Magdalenian sites of this region, it remains a reference for exploring variations over a very short time period due to its wellpreserved stratigraphic sequence, covering at least one century (Figure 1b; Orliac, 2006). Every year since its discovery in 1964 , the site has been explored via the same planimetric excavation method: every artifact is recorded on a square plan and in 3 dimensions, with altitudes before removal. Today, this method is applied all over the world in open-air site 
103 2014).
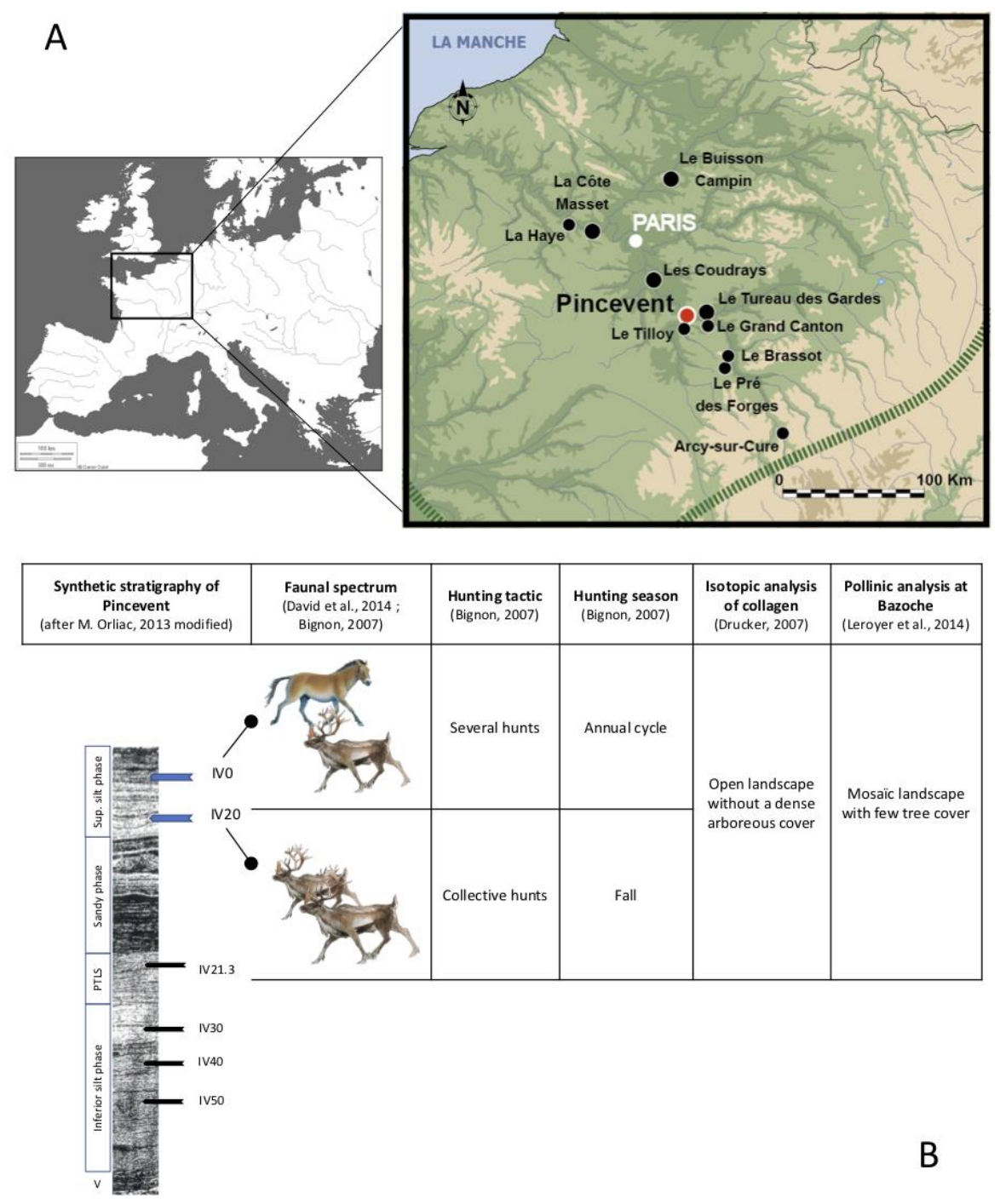

The two best-known levels on the site were excavated during several decades: level 112 IV20 from 1967 to 1995 , and level IV0 from 1989 to 2016. In each level of occupation, the 113 synchronicity of the features is demonstrated by flint and heated stone refits that show a dense 114 network of relationships (Bodu et al., 1993, 2014; SI, map of level IV20) and stratigraphic 
control (Orliac, 2006, 2014).

All of the Magdalenian group occupations at Pincevent are attributed to the Upper Magdalenian period between 14000 and 11800 calBC (Table 1; Valladas, 1994; Debout et al., 2012). The different occupations preserved in the overflow of silt from the Seine indicate seasonal inputs of stream sediments (Roblin-Jouve, 1994), and the strength of the streams suggest precipitations probably due to melting snow (Orliac, 1994). Grain size analysis of the stratigraphic levels indicate environmental fluctuations linked to the Seine's watercourse (Orliac, 2006; Bignon, 2008). These environmental oscillations seem to vary with the high activity of the river, according to the seasons and other environmental factors (Bignon, ibid).

Table 1: Dating Magdalenian levels IV20 and IVO studied here

\begin{tabular}{cccccc}
\hline Level & $\begin{array}{c}\text { 14C BP dates } \\
\text { (*AMS) }\end{array}$ & CalBC dates & $\begin{array}{c}\text { Nature of } \\
\text { sample }\end{array}$ & Reference & Bibliography \\
\hline & $12120 \pm 130$ & $12494-11926$ & Charcoal & Gif 6283 & Valladas (1994), p. 66 \\
& $12600 \pm 200^{*}$ & $13407-12551$ & Bone & OxA 148 & Valladas (1994), p. 66 \\
& $12250 \pm 160^{*}$ & $12860-12072$ & Charcoal & OxA 467 & Valladas (1994), p. 66 \\
& $12450 \pm 45^{*}$ & $13082-12456$ & Charcoal & ETH 37119 & Bodu et al. (2009), p. 93 \\
\hline IV0 & $12460 \pm 70$ & $13084-12202$ & Tooth & Lyon-9397 & Orliac et al. (2013), p. 77 \\
& $12440 \pm 60$ & $13053-12193$ & Bone & Lyon-9398 & Orliac et al. (2013), p. 77 \\
& $12580 \pm 60$ & $13228-12293$ & Tooth & Lyon-9399 & Orliac et al. (2013), p. 77 \\
\hline
\end{tabular}

The Pincevent site is located upstream of a fluvial bottleneck corridor (Figure 1A). Such location, providing constant water and large floodplains, could have favoured concentration of megafauna not far from human occupation; within an ecological community, multiple species of large mammals (especially large herbivores) can coexist in a mosaic landscape (Guthrie, 1982). And the simultaneous occurrence of reindeer and horse in the faunal spectrum in Pincevent emphasizes the scenario presented by Bignon (2008). Indeed, there is 
135

136

137

138

139

140

141

142

143

144

145

146

147

148

149

150

151

152

153

154

155

156

157

158

159

an alternation between two types of spectrum associating horses and reindeer (for instance in level IV0) and the favoring of one species (mass killing of reindeer on level IV20; Enloe et David, 2014; Bignon, 2007; Bignon-Lau, 2014). The site of Pincevent presents these two types of hunting spectrum, which is why it is interesting to focus on this site to interpret the change of tactics from a precise point of view.

Reconstructing the diet of the reindeer killed and consumed in Pincevent was applied to the two most studied levels (IV0 and IV20), reflecting two hunting strategies. As they were most likely hunted either all year round or targeted in a single short time span, and as their dental microwear textures result from the mastication of the food items (and possibly exogeneous particles ingested), we may expect differences between reindeer samples from IV20 and IV0 levels.

Level IV20 was a short-term occupation of Magdalenians in Pincevent (see SI). The predominance of reindeer (Rangifer tarandus) was attested by $98 \%$ of the total amount of bones identified (4,542 bones, David et al., 2014). Identification and ageing of these cervids show a mortality profile very close of natural populations even if 3-5 years old adults seems slightly overrepresented as well as male vs female adults (respectively 58 vs $42 \%$, considering morphometric data). Moreover, the amount of reindeer found at this level $(\mathrm{MNI}=76$ Minimum Number of Individual - Table 2; Enloe \& David, 2014), is likely to have been the result of one or a very few massive hunting episode(s). Such hunting activities happened during a very short window of time, in early fall, considering a set of considerations (David et al., 2014):

- this seasonality is consistent with observations of teeth composition and wear (eruption rate of juveniles; Miller, 1974; Enloe \& David, 2014);

- no foetal or new born bones have been found, indicating winter or spring occupations; 
- only antler from hunted animals, both males and females were found (no shed ones), meaning that these specimens were killed between summer and early winter periods; however, only fall migration can provide such massive fusion of smallest male or female bands.

164 Besides these archaeozoological arguments, it has been established that the lithic production reflects an occupation lasting no more than two or three weeks (Julien, Karlin, 2014); such estimation of duration is in agreement with the clear spatial organization of units showing a few rates of rearrangements (areas of specialized work, toss zones, cleaning processes, etc.). IV20 has been interpreted as a residential camp set up at a reindeer fall migration route, exhibiting a massive interception of such animal resource. We expect DMTA (Dental year.

Table 2: Faunal and other remains'data for IV20 and IVO levels in Pincevent (locus regrouped)

\begin{tabular}{|c|c|c|c|c|}
\hline & \multicolumn{2}{|c|}{ Occupation level } & IV20 & IV0 \\
\hline \multirow{7}{*}{ Fauna } & \multicolumn{2}{|c|}{ Excavated surface $\left(\mathrm{m}^{2}\right)$} & 4500 & 1500 \\
\hline & \multicolumn{2}{|c|}{ NR } & 4643 & 22076 \\
\hline & \multicolumn{2}{|c|}{ NRD } & 4600 & 2870 \\
\hline & \multirow{2}{*}{ NR $(\%)$} & Rangifer & 98 & 63.13 \\
\hline & & Equus & 0.8 & 32.27 \\
\hline & \multirow{2}{*}{ MNI } & Rangifer & 76 & 46 \\
\hline & & Equus & 2 & 34 \\
\hline \multirow{2}{*}{ Heated stone } & \multicolumn{2}{|c|}{ NR } & & 13000 \\
\hline & \multicolumn{2}{|c|}{ Weight total (tonnes) } & & 1.5 \\
\hline \multirow{2}{*}{ Ornament } & \multicolumn{2}{|c|}{ NR } & & 298 \\
\hline & \multicolumn{2}{|c|}{ Shells (NR) } & & 270 \\
\hline Lithic remains & \multicolumn{2}{|c|}{ NR } & $30000 / 4500 \mathrm{~m} 2$ & $18000 / 1400 \mathrm{~m} 2$ \\
\hline
\end{tabular}


Table 3: Taphonomy of level IVO and IV20 - weathering (from A.K. Behrensmeyer, 1978) and destruction of the surface of the bone by the roots (B) - in David et al., 2014 p.79.

\begin{tabular}{|c|c|c|c|}
\hline \multicolumn{2}{|c|}{ Taphonomy } & \multirow{2}{*}{$\begin{array}{c}\text { IV0 (\%) } \\
3.96\end{array}$} & \multirow{2}{*}{$\begin{array}{c}\text { IV20 (\%) } \\
49.9\end{array}$} \\
\hline \multirow{5}{*}{ (A) } & 1 & & \\
\hline & 2 & 11.08 & 35.6 \\
\hline & 3 & 54.59 & 10.8 \\
\hline & 4 & 25.88 & 2.9 \\
\hline & 5 & 4.49 & 0.6 \\
\hline \multirow{4}{*}{ (B) } & 1 & 3.09 & 45.9 \\
\hline & 2 & 3.92 & 34.6 \\
\hline & 3 & 6.53 & 15.2 \\
\hline & 4 & 86.46 & 4.2 \\
\hline
\end{tabular}

Level IV0 represents the very last Magdalenian occupation preserved at Pincevent (Bodu et al., 2006). According to the sandy silt count from that level, there is around twenty year difference between the occupation of level IV20 and the occupation of level IV0, which is slightly inferior to the radiocarbon dating resolution for the Paleolithic period (Orliac, 2006 ; 2014). At this level, the camp seems to have been, uncommonly, heavily structured by heated stones. This partially excavated camp was organized according to four units linked by refits of heated stones and/or lithic productions (Bodu, 2013). Unit 43-T125 was published in 2006 and the recent work on all units (35-M103, 35-D110 and 25-V97) will be published in a monography currently in preparation (pers. com.).

In some localized parts of the level (20-30 $\mathrm{cm}$ under the surface), low and localized bioturbation is due to vegetation and burrowing animals (Table 3). Despite this situation, the occupation repartition and bioturbations did not impede economical interpretations concerning Magdalenian choices. With an almost equal amount of reindeer and horse remains (Reindeer: $\mathrm{MNI}=43$; Horses: $\mathrm{MNI}=33$, Table 2), hunting strategies were most likely different. The occupation on this level is typical of a "predominant association of horsereindeer": these two species represented almost $85 \%$ of the total number of remains (Table 2 , Bignon, 2007; Bignon-Lau, 2014). 

permanent teeth), dental crown height method and dental stage wear (Miller, 1974; crown-

211 height method; Bignon-Lau, 2006, 2007). In level IV0, it appears that the animals were killed

212 during multiple non-massive hunts throughout the year (Figure 1b). In contrast with 213 archaeozoological data in level IV0, the amount of lithic production is similar to level IV20. 214 This level shows a massive and entangled organization with numerous activities and phases 215 of waste disposal regrouped. Finally, it very likely seems that, a serie of multiple brief 216 occupations results in such seasonality data and the level IV0 spatial organization of remains 217 (Bodu et al., 2006; Debout, 2012).

We expect DMTA to reflect a largest variability of feeding habits and help us to 219 consider possibly a greater landscape image where happened these different hunting 220 strategies.

\section{3 - MATERIAL AND METHOD}

\section{1 - Material}

We selected only teeth that presented an optimal enamel surface conservation, that is similar at the scale of 3D scanning of surfaces to the ones of modern reindeer teeth. Faunal 225 remains from level IV20 were better preserved than those from level IV0 (Table 3), but in accordance with our selection criteria, such different taphonomic contexts did not have any

227 effect on specimens analysed. However, more pronounced taphonomic alterations on level 228 IV0 lead to a much higher rate of rejected specimens. This greatest selection process from 229 level IV0 have been amplified because its MNI is smaller than from level IV20. For level IV0, 230 we selected 13 teeth from a total of 46 individuals (Bignon-Lau, 2019). For level IV20, 55 out 231 of 76 individuals (from sections 36 and 27; Julien \& Karlin, 2014) were selected to be 232 analyzed. 
234 Norwegian tundra adult reindeer from Knushø $(\mathrm{N}=48)$ and Hardangervidda $(\mathrm{N}=54$; Bignon-

235 Lau et al., 2017), to interpret any intraspecific diet signal variations or mobility pattern

236 variations of regional population from present and past reindeer populations. The reindeer

237 populations in Knutshø and Hardangervidda belong to the Norwegian National Monitoring

238 Program for wild cervids. As part of this program, lower jaws are collected from animals shot

239 during the regular hunting season (the middle of August to the beginning of October).

\section{2 - Method}

DMTA was performed on disto-labial facets on the protoconid of lower molars (Figure

242

2A). Priority was given on M2 and complement was made with homologous dental facets on third or first molars following Ramdarshan et al. (2017) recommendations.

Following standard procedures, teeth were cleaned and molded with a polyvinyl siloxane (Coltène Whaledent, President Regular Body). Rather than producing a transparent resin-based cast, the molds were scanned directly using the "TRIDENT" confocal surface profilometer DCM8 Leica Microsystems, housed at the Palevoprim laboratory (CNRS-INEE and the University of Poitiers). The profilometer was equipped with a $100 \times$ lens (Numerical aperture $=0.90 ;$ working distance $=0.9 \mu \mathrm{m})$ and a $331 \times 251 \mu \mathrm{m}$ area was scanned for each specimen. From this, four sub-adjacent surfaces $(140 \times 100 \mu \mathrm{m})$ were generated following procedures shown in Berlioz et al. (2018), and pre-treated following Merceron et al. (2016) and saved as Pl $\mu$ files. The lateral sampling interval was $0.129 \mu \mathrm{m}$ and the vertical spacing was $0.002 \mu \mathrm{m}$. Further analyzes to generate DMTA variables were conducted with Toothfrax, following procedures and settings provided by Scott et al. (2006).

Here, we focused on the four DMTA variables of the five detailed by Scott et al. (2006): complexity (Asfc), anisotropy (epLsar) and heterogeneity of complexity (HAsfc9 ; Table 4; Scott 2012). Scott (2012) concludes that complexity (Asfc) is positively correlated with the lignified tissues of woody vegetation, and negatively correlated to the amount of 
abrasive (silica-bearing) monocots in a diet, whereas the anisotropy of the texture (epLsar) is

260 positively correlated to the amount of tough vegetation such as grasses or mature tree leaves

261 in the diet (see also Ungar et al., 2007). According to previous studies on extant species and

262 sheep raised and fed in captivity (Merceron et al., 2014; Souron et al., 2015; Ramdarshan \&

263 Merceron, 2016), the heterogeneity of complexity is positively correlated to the diversity of

264 diet. Variations in dental microwear textures among the archeological and modern populations

265 of reindeer were tested using Statistica software, by combining non-parametric Kruskal Wallis

266 analysis of variances and post-hoc comparisons of mean ranks of all pairs of groups with a

267 Bonferroni adjustment (Table 5).

Table 4: Textural data on levels studied at Pincevent.

\begin{tabular}{|c|c|ccc|ccc|ccc|}
\cline { 2 - 10 } \multicolumn{2}{c|}{} & \multicolumn{3}{c|}{ Asfc } & \multicolumn{3}{c|}{ epLsarx10-3 } & \multicolumn{3}{c|}{ HAsfc 9 } \\
\hline Sites & $\mathbf{n}$ & mean & s.d. & s.e.m. & mean & s.d. & s.e.m. & mean & s.d. & s.e.m. \\
\hline Level IV0 & 13 & 1.716 & 0.724 & 0.201 & 3.520 & 1.858 & 0.515 & 0.587 & 0.212 & 0.059 \\
Level IV20 & 55 & 1.169 & 0.489 & 0.066 & 5.453 & 1.876 & 0.253 & 0.389 & 0.205 & 0.028 \\
Hardangervidda & 54 & 2.344 & 1.043 & 0.142 & 3.255 & 1.393 & 0.190 & 0.525 & 0.195 & 0.026 \\
Knutshø & 48 & 1.865 & 0.641 & 0.092 & 4.361 & 1.867 & 0.270 & 0.513 & 0.161 & 0.023 \\
\hline
\end{tabular}

Table 5: Results of the non-parametric Kruskal Wallis analysis of variances and synthetic results of the post hoc multicomparisons test including reindeer from level IV20, level IV0 and the two Norwegian dataset (Knutshø and Hardangervidda).

\begin{tabular}{cccc}
\hline Variables & $\mathrm{K}$ & $\mathrm{Df}$ & $\mathrm{p}$-value \\
\hline $\boldsymbol{A s f \boldsymbol { c }}$ & 52.30433 & 3 & $<0.0001$ \\
$\boldsymbol{\text { epLsar }}$ & 34.86051 & 3 & $<0.0001$ \\
$\boldsymbol{H} \boldsymbol{A} \boldsymbol{s} \boldsymbol{c} \boldsymbol{g}$ & 29.47611 & 3 & $<0.0001$ \\
\hline
\end{tabular}

\begin{tabular}{|c|c|c|c|c|}
\hline & Hardangervidda & Knutshø & Level-IV0 & Level-IV20 \\
\hline \multicolumn{5}{|l|}{ Hardangervidda } \\
\hline Knutshø & epLsar & & & \\
\hline \multicolumn{5}{|l|}{ Level-IV0 } \\
\hline Level-IV20 & Asfc. epLsar. HAsfe 9 & Asfc. epLsar. HAsfc ${ }_{9}$ & epLsar. HAsfc 9 & \\
\hline
\end{tabular}




\section{4 - RESULTS - Pincevent's reindeer diet}

The Kruskal-Wallis analysis of variance detected significant variations for all of the

279 texture parameters (Table 4 and 5). The observed differences between the reindeer from the

280 IV20 level and the two modern samples were all significant (Table 5, Figure 2). The reindeer

281 from the level IV0 does not differ the modern population for any of the textural parameters.

282 The reindeer from the IV20 level showed significantly higher value in anisotropy (epLsar)

283 and lower one in heterogeneity of complexity (HAsfc9) compared with the cervids from level

284 IV0 (Table 5, Figure 2).

A
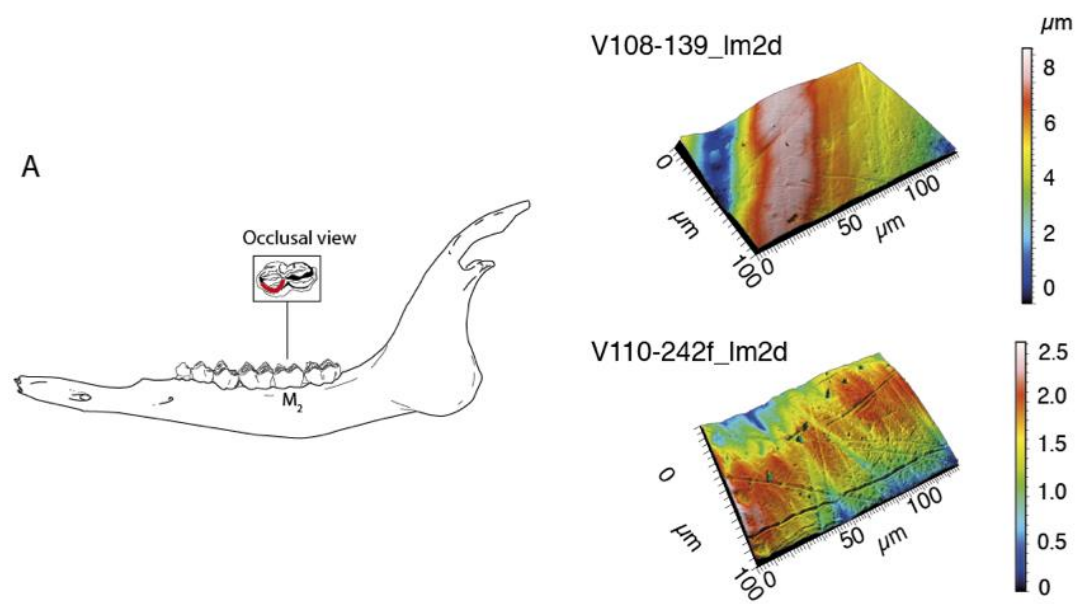

B

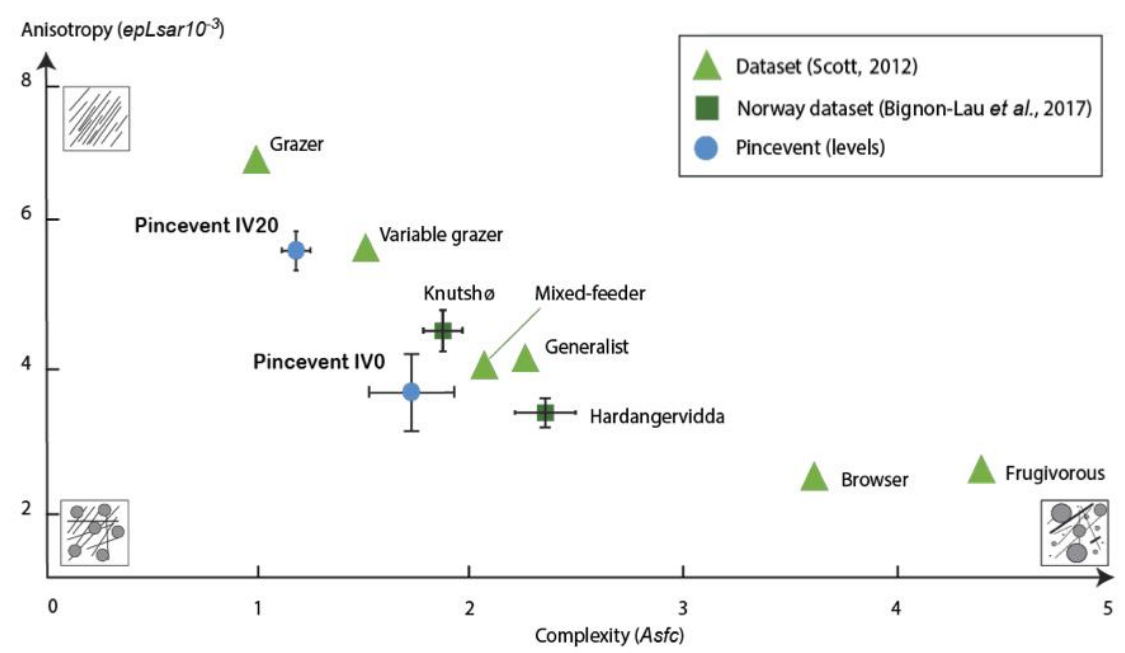

Figure 2: Sampling (in red) of an adult specimen (CAD - A. Lau-Bignon) (A), complexity in the anisotropy of 


\section{5 - DISCUSSION}

\subsection{Diet of reindeer and environments}

The dental microwear textures of the reindeer from level IV0 supported similarities in dietary bolus with the two modern populations, which inhabit alpine tundra landscapes. Their winter diet is dominated by lichens $(62 \%)$, woody plants $(16.3 \%)$, low percentages of mosses $(8.6 \%)$, and herbaceous monocotyledons (grasses, sedges, rushes; 6.3\%, Skogland, 1984; Bignon-Lau et al., 2017). However, these reindeer were slaughtered in late summer (from late August till early October) a period during which the diet is more balanced with herbaceous monocots (more than 45\%), lichens (about 16\%) and shrubs (11\%) of the stomach content. Bignon-Lau et al. (2017) have shown that the dental microwear textures of the two modern populations of reindeer reflect these mixed feeding habits in late summer, although the Knutshø population are more engaged in grazing in herbaceous monocotyledons than the Hardangervidda samples. Differences in population density are most likely the main parameter controlling the dietary spectrum; thus, explaining the differences in dental microwear textures between the two populations. Due to a higher individual competition for access to food resources, the individuals of the Hardangervidda population probably had to enlarge their dietary spectrum to include more browsing and more lichens than the Knutshø population. There is no doubt, therefore, that the reindeer from level IV0 were engaged in both grazing and browsing.

The reindeer from level IV20 were significantly more engaged in grazing than the Knutshø ones (Figure 2b). When plotting the reindeer data on the "complexity versus anisotropy" continuum based on the African bovidea data (which are used as illustrative reference for herbivores living in pasture ecosystem), Figure 2; Scott, 2012), the reindeer from level IV20 fell between variable and obligate grazers. Such dental microwear textures support either that the food resources were abundant enough to provide full access to the preferred food 
resources, or that the reindeer herds were not large enough to avoid individual competition for

316 food resources. Taking into account the archeological context, the former hypothesis seems 317 to be correct.

Paleoenvironmental reconstruction in the Paris Basin during the Late Glacial indicates a mammoth steppe ecosystem, characterized by an association of communities of megaherbivores and a mosaic landscape (Guthrie, 1982, 1984, 1990; Bignon, 2008). This is confirmed by pollinic analyzes conducted in Bazoches-les-Brès, 5 kilometers from the Pincevent site. The pollen spectrum attests to a steppic type of flora with a dominance of herbaceous dicots (zone Baz a,b,c between 15 and 20\% of Rubiaceae and Compositeae; Leroyer et al., 2014) and monocots (zone Baz a,b,c between 30 and $40 \%$ of Poaceae and Cyperaceae ; Leroyer et al., 2014). This is consistent with isotopic analysis conducted on these regional sites which depicted an open environment without dense tree cover (tundra, grasslands; Drucker, 2001). The herbivores found in the Paris Basin sites would have frequented a tundra-like environment (with less lignified or semi-lignified shrubs and bushes, however). They actually have higher $\delta^{13} \mathrm{C}$ values of collagen than herbivores from dense tree cover landscapes (Drucker, 2001). In the case of the IV0 and IV20 levels, reindeer "mean values of ${ }^{13} \mathrm{C}_{\text {coll }}$ are set between -19.5 et $-20.5 \%$ " (Drucker, 2007; translated from French by the authors, p. 251), indicating that they undoubtedly frequented an open environment.

\subsection{A shift in reindeer behavior}

In Pincevent, researchers generally tend to place the culling event of the IV20 occupation during the animals' fall migration (mortality profile, sex-ratio, seasonal arguments, short-term occupation indicated by low flint production and spatial organization), which indicates that the herd was looking for more abundant food resources (David et al., 2014). The tactic developed by Magdalenian people at this time of year is consistent with the mortality 
profile of a natural population: seasonal information (age of juveniles), the reindeer's MNI, as

343 well as the short duration of the camp (see SI for details; Julien, Karlin, 2014). Dental

344 microwear textural analyses of the IV20 reindeer show a strikingly narrow inter-individual

345 variability, an homogeneity that fits well with the short period of the fall culling event (Figure 346 2B).

347 On the contrary, less massive tactics were developed twenty years later during the IV0 348 occupation, with multiple hunting events occurring all year round. This yields a more complex 349 reindeer mortality profile (underrepresentation of juveniles, while young adults are 350 overrepresented) and denser units revealing the inner reorganization dynamics of the camp (SI; 351 Bodu et al., 2006, 2011; Debout, 2012). We noted that the species targeted also changed: in 352 level IV20, reindeer represent almost all of the faunal spectrum, whereas level IV0 was shared 353 between reindeer and horses. When one is considering the largest period of reindeer hunts from 354 level IV0, embracing all seasons, it is not surprising to find a significantly greater inter355 individual variability of microwear values compared to level IV20 specimens (Figure 2b). In 356 addition, beyond the range of inter-individual diet variability we pointed out that there was no 357 significant overlap of the data (including standard deviation for Asfc and epLsarx $10^{-3}$ in Figure $3582 \mathrm{~b}$, table 4) between level IV20 and IV0. Though several reindeer were hunted in fall in both 359 levels (unit 43-T125 for level IV0; Debout et al., 2006), the diet variability highlighted in this 360 paper was not restricted to cyclic seasonal fluctuations. These considerations, therefore, lead us 361 to consider that such targeted animals changed their feeding behavior during a short timespan 362 of twenty years.

363 5.3. Consequences and causes of changes in reindeer behavior

364 From a Magdalenian hunter's point of view, such a significant shift in behavior concerning 365 one of their key-species was crucial for their whole settlement pattern and potentially for their 366 survival. We may hypothesize that resource availability influenced animal distribution and 367 density due to their movements or migrations (Skogland, 1989; Bennett, Provan, 2008; 
368 Hopcraft et al., 2010). In turn, reindeer availability and density all year round, or at some 369 predictable moments in case of migration, depends on hunting tactics, a collaborative amount 370 of people needed and the patterns of mobility of Magdalenian hunter-gatherers (Binford, 371 1978; Bignon, 2008; Julien, Karlin, 2014). In extant reindeer populations, we can observe 372 different type of migratory behavior. Rangifer tarandus can be sedentary when they are not 373 predated or live without demographic pressure, or can be generally sedentary-migratory when 374 only a part of the population is migratory (Reimers, 1983; Tyler and Oritsland, 1989; Geist, 375 1999; Loe et al., 2007; Kuntz, 2011). Migratory reindeer (entire herds) can cover very long 376 distance through winter or summer pastures. Regarding resource availability, we know that abiotic factors (such as rainfall or soil nutrients) can impact forage quality and abundance, resulting in herbivores of different sizes 379 (Hopcraft et al., 2010). During the Magdalenian occupation, the environment was open but 380 fluctuations were registered during the Bölling period, according to sedimentology studies 381 (Orliac,2006). In fact, slight modifications of sediment composition occured between the silt 382 deposit of IV20 level and the sandy silt deposit corresponding to IV0 level (Orliac,2006). The 383 latter sediment composition indicates slightly more force than the Seine, due to higher rainfall 384 or snowfall rates (Orliac,2006). Regarding such fluctuations, rain/snowfall variation are of importance for plant's composition and abundance: reindeer could have been helped by searching for more quality foraging. Would the paleoenvironmental conditions that could have

387 favored a shift in reindeer feeding behavior might also have led to migratory behavior? Regarding level IV20, this very well preserved camp strongly suggests that the reindeer 389 were migrating (David et al, 2014). Conversely, the dental microwear texture of reindeer on 390 level IV0 is closer to the two Norwegian extant populations (Figure 2b, Table 5): different 391 seasons with different vegetal resources. We can therefore hypothesize that the reindeer from 392 level IV0 were less migratory than the reindeer from level IV20. But at this point, several 
393 complementary analyzes (DMTA for broader spectrum of sites, and confrontation with intra-

394 tooth oxygen, carbon and strontium isotope variations) are needed to precise which scenario 395 could be the best one:

396 - level IV20 specimens were migratory but level IV0 ones were sedentary;

397 - level IV20 specimens were migratory but level IV0 ones became mixed sedentary-migratory 398 population;

399 - specimens of both levels were mixed sedentary-migratory populations and Magdalenian 400 changed their hunting tactics while reindeer got better physical condition.

401

\section{6 - CONCLUSION}

By analyzing the dental microwear texture of the 68 reindeer hunted by Magdalenians 404 and found in Pincevent, we have been able to identify variations of diet in reindeer between 405 levels IV0 and IV20. The signal provided complements those provided by the isotopic analyzes of bone collagen applied on the same levels. Variability of reindeer behavior suggests variability among hunting strategies during the Upper Paleolithic period. To establish hunting strategies people must have gathered a thorough knowledge of reindeer 409 and horse ethology (migration paths, calving grounds). The hunters probably knew where to 410 find their prey, which is why reconstructing animal ethology with proxies, such as dental 411 microwear texture or isotopic analyzes, is important for reconstructing hunting strategies.

412 Reconstructing diet behavior in reindeer helped us define the Magdalenian's way of life in 413 the Paris Basin more precisely, and enabled the coevolution bond that persisted throughout 414 this period to be established.

\section{Acknowledgements}

417 We would like to thank the Ethnologie prehistorique laboratory and LabEx DynamiTe G3.1 
"Changements environnementaux et sociétés dans le passé" for their financial support, and

419 the Pincevent team for lending us the faunal samples. We are also grateful to E. Berlioz and

420 A. Ramdarshan. N. C. would like to thank M. Plasse for his moral support in this adventure.

421 Finally, N. C. would like to thank M. Christensen for her time and valuable advice on the

422 work in progress.

\section{References}

Ballinger M., Bignon-Lau O., Bodu P., Debout G., Dumarçay G., Hardy M., Julien M., Karlin : 50 années de recherches sur la vie des Magdaléniens, CAP et SPF.

Berlioz E., Azorit C., Blondel C., Ruiz M.S.T., Merceron G., 2017. Deer in an arid habitat: dental microwear textures track feeding adaptability. Hystrix - The Italian Journal of Mammalogy 28.

Bignon O., 2003. Diversité et exploitation des équidés au Tardiglaciaire en Europe occidentale : implications pour les stratégies de subsistance et les modes de vie au Magdalénien et à l'Azilien du Bassin parisien, Paris X, Nanterre, 856 p.

Bignon O., 2006. «De l'exploitation des chevaux aux stratégies de subsistance des Magdaléniens du Bassin parisien », Gallia préhistoire, 48, 1, p. 181-206.

Bignon O., 2007. L'autre « civilisation du Renne ». Pour une réinterprétation des stratégies cynégétiques au Magdalénien dans le Bassin parisien, in Les civilisations du renne d'hier et d'aujourd'hui. Approches ethnohistoriques, archéologiques et anthropologiques. Antibes, France, APDCA, p. 223-241.

Bignon O., 2008. Chasser les chevaux à la fin du Paléolitique dans le Bassin parisien : stratégie cynégétique et mode de vie au Magdalénien et à l'Azilien ancien, Oxford, Royaume-Uni de Grande-Bretagne et d'Irlande du Nord, British Archaeological Reports International Series, 170 p.

Bignon O., Enloe J.G., Bemilli C., 2006. Chapitre II.1 : Étude archéozoologique de l'unité T125 : originalité de la chasse des rennes et des chevaux. In Bodu P., Julien J.,Valentin V., Debout G. (dir.), Un dernier hiver à Pincevent : les Magdaléniens du niveau IV0. Gallia Préhistoire, t. 48, p. 18-35.

Bignon-Lau O., 2014. « Hunting practices targeting large mammal communities in the Paris

Bignon-Lau O., Catz N., Berlioz E., Veberg V., Strand O., Merceron G., 2017. Dental Microwear Textural Analyses to track feeding ecology of Reindeer: a comparison of Knutshø and Hardangervidda populations, Norway. Mammal Research, vol. 62, pp.111-120 
Bodu P., Debout G., 2006. Le travail du silex, in P. Bodu, M. Julien, B. Valentin et G. Debout

(dir.), « Un dernier hiver à Pincevent : les magdaléniens du niveau IV0 (Pincevent, La Grande-Paroisse, Seine-et-Marne) », Gallia Préhistoire, 48, pp. 251-256

Bodu P., Julien M., Valentin, B., Debout G., 2006. Un dernier hiver à Pincevent : les magdaléniens du niveau IV0 (Pincevent, La Grande-Paroisse, Seine-et-Marne), Gallia Préhistoire, 48, pp.1-180.

Bodu P., 2013. Niveau IV0 - Opérations de fouille en 2013 à la lumière des résultats obtenus les années précédentes, Fouille programmée du site de Pincevent (La Grande-Paroisse, Seinet-Marne

Calandra I., Merceron G., 2016. Dental microwear texture analysis in mammalian ecology: DMTA in ecology. Mammal Review 46, 215-228.

Danell K., Bergström R., Duncan P., Pastor J., 2006. Large Herbivore Ecology, Ecosystem Dynamics and Conservation, Cambrigde University Press.

David F., 1994. La faune de mammifères de Pincevent et Verberie, in Taborin (dir.), Environnements et habitats magdaléniens dans le centre du Bassin parisien, Paris, éditions de la Maison des sciences de l'homme (DAF, 43), pp. 105-174

David F., Enloe J.G., Mourer-Chauviré C., Bignon-Lau O., 2014. « La faune : espèces chassées, consommées ou utilisées », in Un automne à Pincevent : Le campement magdalénien du niveau IV20, p. $77-83$.

Debout G., Olive M., Bignon O., Bodu P., Chehmana L., Valentin B., 2012. « The Magdalenian in the Paris Basin: New results », Quaternary International, 272-273, p. 176-190.

Drucker D., 2001. Validation méthodologique de l'analyse isotopique d'ossements fossiles et apports aux reconstitutions paléoécologiques du Paléolithique suprieur du sud-ouest de la France., Paris VI, 206 p.

Drucker D., 2007. Les Cervidés durant le Tardiglaciaire et l'Holocène ancien en Europe occidentale : approche isotopique. In Beyries S. et Vat. V. (Ed.): Les civilisations du Renne d'hier et d'aujourd'hui. Approches ethnohistoriques, archéologiques et anthropologiques, XXVIIe rencontres internationales d'archéologie et d'histoire d'Antibes. APDCA, Antibes, p. 243-254.

Enloe J. G., 1994. Comparaison entre les troupeaux de rennes de Pincevent et de Verberie. In : Taborin Y. (dir.), Environnements et habitats magdaléniens dans le centre du Bassin parisien. Paris : Maison des Sciences de l'Homme (Documents d'Archéologie Française n ${ }^{\circ}$ 43), p. 115 117.

Enloe J.G., 1998. Fonctions des sites et chasses spécialisée : variations régionales pendant la période magdalénienne, in J.-P. Brugal, L. Meignen et M. Patou-Mathis (dir.), Economie préhistorique : les comportements de subsistance au Paléolithique, Sophia-Antipolis, éditions APDCA, pp. 363-372. 
Enloe J. G., 2000a. Le Magdalénien du Bassin parisien au Tadiglaciaire : la chasse au rennes comparée à celle d'autres espèces. In : Pion G. (dir.), Le Paléolithique supérieur récent : nouvelles données sur le peuplement et l'environnement. Actes de la Table ronde de Chambéry 12-13 mars 1999, Mémoire XXVIII. Paris : Société Préhistorique Française, pp. 39-45.

Enloe J. G., 2000b. Readaptation : changes in Magdalenian subsistence and social organization. In: Peterkin G. L. \& Price H. A. (eds), Regional approaches to adaptation in Late Pleistocene Western Europe. Oxford: British Archaeological Reports International Series, 896, p. 115-120

Geist V. 1999. Deer of the World: Their Evolution, Behaviour, and Ecology, Swan Hill Press.

Guthrie R.D. 1982. "Mammals of the mammoth steppe as paleoenvironmental indicators", p. 307-329.

Guthrie R.D. 1984. «Mosaics, allelochemics, and nutrients. An ecological theory of Late Pleistocene megafaunal extinction », Quaternary extinctions, p. 259-298.

Guthrie D.R., 1990. Frozen fauna of the Mammoth Steppe: the story of the Blue Barbe. University of Chicago Press, 323 p.

Hopcraft J.G.C., Olff H., Sinclair A.R.E., 2010. Herbivores, resources and risks: alternating regulation along primary environmental gradients in savannas. Trends in Ecology \& Evolution, 25(2), 119-128.

Julien M., Karlin C., 2014. Un automne à Pincevent - Le campement magdalénien du niveau IV20. Paris, Société préhistorique française, Mémoire $n^{\circ} 57$.

Kelly R.L., 1983. « Hunter-Gatherer Mobility Strategies », Journal of Anthropological Research, 39, 3, p. 277-306.

Kuntz D., 2011. Ostéométrie et migration(s) du renne (Rangifer tarandus) dans le Sud-Ouest de la France au cours du dernier Pléniglaciaire et du Tardiglaciaire (21 $500-13000 \mathrm{cal}$. $B P)$, phdthesis, Université Toulouse le Mirail - Toulouse II.

Leader-Williams N., 1988. Reindeer on South Georgia, the ecology of an introduced population. Cambridge University Press, Cambridge, 319 p.

Leduc C., 2010. Acquisition et exploitation des ressources animales au Maglemosien : essai de reconstitution des chaînes opératoires globales d'exploitation d'après l'analyse des vestiges osseux des sites de Mullerup et Lundby Mose (Sjaelland-Danemark), Paris 1.

Leroi-Gourhan A., Brézillon M., 1966. L’habitation magdalénienne $n^{\circ} 1$ de Pincevent, près de Montereau (Seine-et-Marne). Gallia Préhistoire, 9, p. 263-385.

Leroi-Gourhan A., Brézillon M., 1972. Fouilles de Pincevent : essai d'analyse ethnographique d'un habitat magdalénien (la section 36). Paris, CNRS Editions, Gallia Préhistoire, VII ${ }^{\mathrm{e}}$ supplément. 
Leroyer C. 1999. Homme, climat, végétation au tardi- et postglaciaire dans le Bassin parisien : apports de l'étude palynologique des fonds de vallée, Lille, France, Atelier national de Reproduction des Thèses.

Leroyer C., Allenet de Ribemont G., Chaussé C., 2014. « Le paysage végétal durant le Tardiglaciaire : Bazoches-lès-Bray, une référence pour le site de Pincevent », in Un automne à Pincevent : Le campement magdalénien du niveau IV20, p. 39-48.

Loe L.E., Bonenfant C., Mysterud A., Severinsen T., Øritsland N.A., Langvatn R., Stien A., Irvine R.J., Stenseth N.C., 2007. "Activity pattern of arctic reindeer in a predator-free environment: no need to keep a daily rhythm », Oecologia, 152, 4, p. 617-624.

Merceron G., Hofman-Kamińska E., Kowalczyk R., 2014. «3D dental microwear texture analysis of feeding habits of sympatric ruminants in the Białowieża Primeval Forest, Poland », Forest Ecology and Management, 328, p. 262-269.

Merceron G., Ramdarshan A., Blondel C., Boisserie J.-R., Brunetiere N., Francisco A., Gautier D., Milhet X., Novello A., Pret D., 2016. Untangling the environmental from the dietary: dust does not matter. Proceeding Royal Society of London. B. 283, 20161032

Orliac M. 1975. Empreintes au latex des coupes du gisement magdalénien de Pincevent : technique et premiers résultats (Mémoires, 20), 2 vol., 171p.

Orliac M. 1994. «Le climat de Pincevent : données issues de l'observation des sédiments. », in Environnements et habitats magdaléniens dans le centre du Bassin parisien., p. 36-39.

Orliac M. 2006. «Position stratigraphique du niveau IV0 », in Bodu P., Julien M., Valentin B., Debout G. (dir.), Un dernier hiver à Pincevent: les Magdaléniens du niveau IVO (Pincevent, La Grande Paroisse, Seine-et-Marne) (coll. Gallia Préhistoire,).

Orliac M., Julien M., Bodu P., Enloe J.G., 2014. Mise en evidence d'un campement, in Julien M. et Karlin C. (dir.), Un automne à Pincevent : le campement magdalénien du niveau IV20, pp. 63-69

Ramdarshan A., Merceron G., 2016. What do fossil samples actually represent? Dental facet and tooth representativity in performing repeatable dental microwear textural measurements. Journal of Human Evolution, 51(4), 339-349.

Ramdarshan, A., Blondel, C., Brunetière, N., Francisco, A., Gautier, D., Surault, J., Merceron, G., 2016. Seeds, browse, and tooth wear: a sheep perspective. Ecology and Evolution 6, $5559-5569$.

Ramdarshan, A., Blondel, C., Gautier, D., Surault, J., Merceron, G., 2017. Overcoming sampling issues in dental tribology: Insights from an experimentation on sheep. Palaeontologia Electronica 20, 1-19.

Reimers E. 1983. «Mortality in Svalbard reindeer », Ecography, 6, 2, p. 141-149. 
Reimers E., Klein D.R., Sørumgård R., 1983. «Calving Time, Growth Rate, and Body Size of

609

610

611

612

613

614

615

616

617

618

619

620

621

622

623

624

625

626

627

628

629

630

631

632

633

634

635

636

637

638

639

640

641

642

643

644

645

646

647

648

649

650

651

652

653

654

Norwegian Reindeer on Different Ranges », Arctic and Alpine Research, 15, 1, p. 107-118.

Roblin-Jouve A., 1994. Le milieu physique, in Y. Taborin (dir.) Environnements et habitats magdaléniens dans le centre du Bassin parisien, éditions de la Maison des sciences de l'homme (DAF, 43), pp. 12-35.

Scott R.S., Ungar P.D., Bergstrom T.S., Brown C.A., Child B.E., 2006. Dental microwear texture analysis: technical considerations. Journal of Human Evolution 51: 339-349.

Scott J.R. 2012. « Dental microwear texture analysis of extant African Bovidae », mammalia, 76, 2, p. 157-174.

Skogland T., 1984. Wild Reindeer Foraging-Niche Organization. Holarctic Ecology, 7 (4): 345379.

Skogland T., 1989. « Natural Selection of Wild Reindeer Life History Traits by Food Limitation and Predation », Oikos, 55, 1, p. 101- 110.

Souron A., Merceron G., Blondel C., Brunetière N., Colyn M., Hofman-Kamińska E., Boisserie J.-R., 2015. «Three-dimensional dental microwear texture analysis and diet in extant Suidae (Mammalia: Cetartiodactyla)», Mammalia, 79, 3, p. 279-291.

Syroechkovskii E.E, 1995. Wild Reindeer. Smithsonian Institution Librairies, Washington, 290p.

Teaford M.F., Ordean J.O., 1989a. « Differences in the Rate of Molar Wear between Monkeys Raised on Different Diets ». Journal of Dental Research 68, $\mathrm{n}^{\circ} 11$

Teaford, M.F., et Ordean J.O., 1989b. « In vivo and in vitro turnover in dental microwear ». American Journal of Physical Anthropology 80: 447-60.

Teaford M.F., Ungar P.S., Taylor A.B., Ross C.F., Vinyard C.J. Vinyard, 2017. «In Vivo Rates of Dental Microwear Formation in Laboratory Primates Fed Different Food Items ». Biosurface and Biotribology,

Tresset A., 1996. Le rôle des relations homme/animal dans l'évolution économique et culturelle des sociétés des $V^{e}$ et IV millénaires en Bassin parisien. Thèse de Doctorat en PréhistoireEthnologie-Anthropologie, Université Paris I - Panthéon Sorbonne.

Tyler N.J.C., Øritsland N.A., 1989. « Why Don’t Svalbard Reindeer Migrate? », Holarctic Ecology, 12, 4, p. 369-376.

Ungar P.S., Merceron G., Scott R.S., 2007. « Dental Microwear Texture Analysis of Varswater Bovids and Early Pliocene Paleoenvironments of Langebaanweg, Western Cape Province, South Africa », Journal of Mammalian Evolution, 14, 3, p. 163-181. 
Valladas H., 1994. Chronologie des sites du Magdalénien final, in Y. Taborin (dir.), Environnements et habitats magdaléniens dans le centre du Bassin parisien, Paris, éditions de la Maison des sciences de l'homme (DAF, 43), pp.65-68.

Vigne J.-D., 1998. Faciès culturels et sous-système technique de l'acquisition des ressources animales. Application au Néolithique ancien méditerranée. In : Anna A. \& Binder D. (eds.), Production et identité culturelle. Rencontres méridionales de Préhistoire récente, Arles, 1996. Antibes : Editions A.P.D.C.A., p. 27-45.

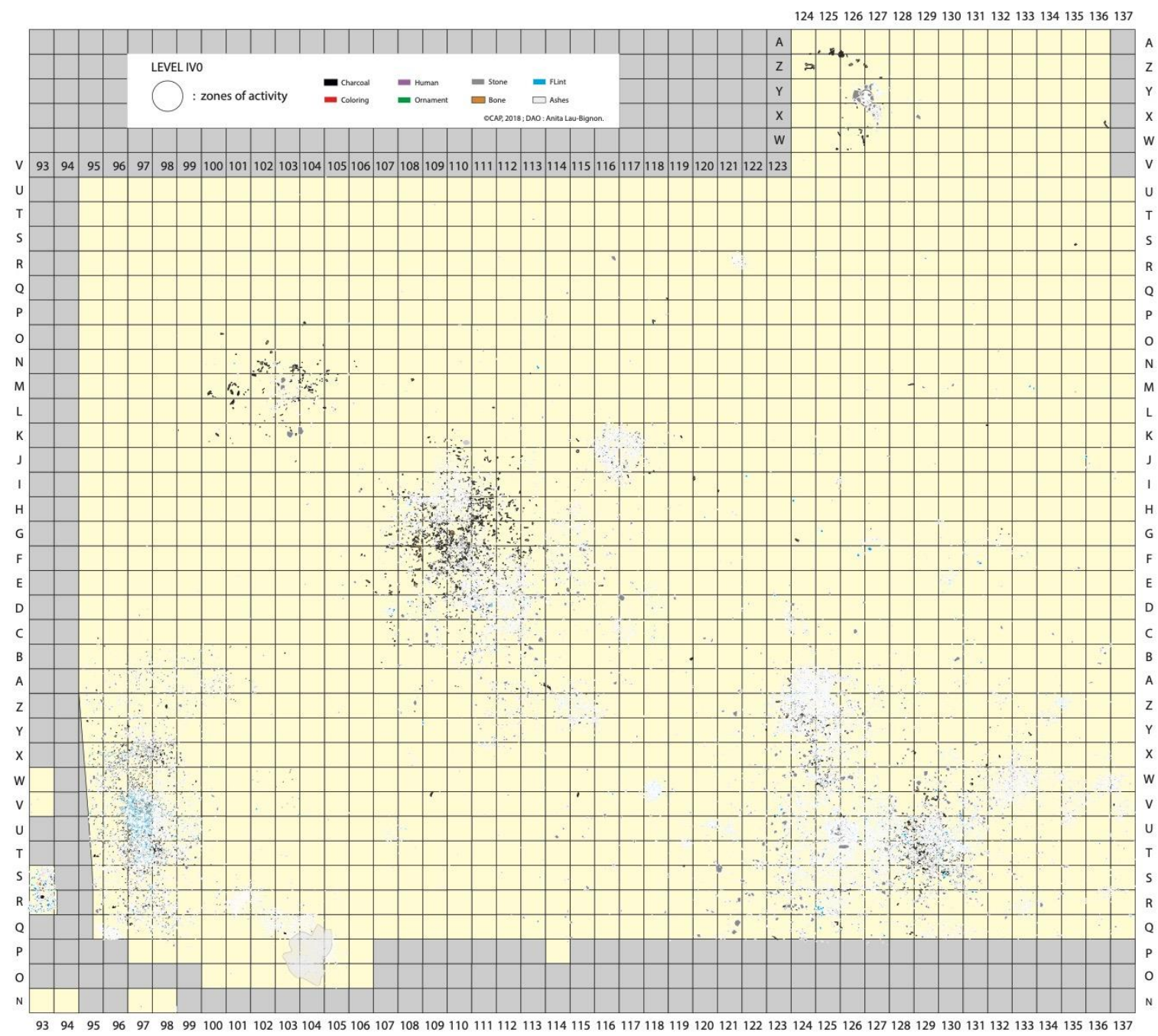



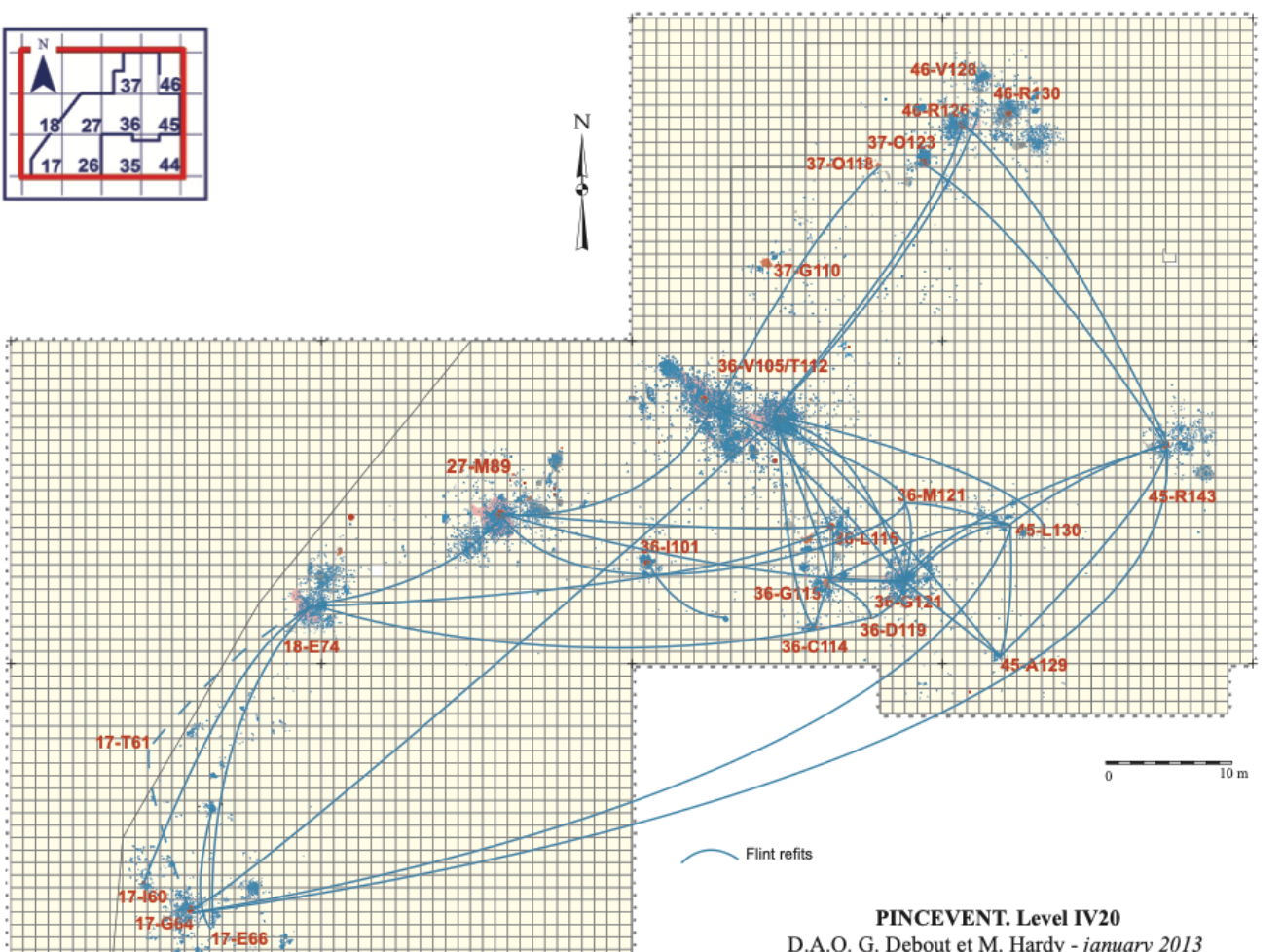

671

D.A.O. G. Debout et M. Hardy - january 2013 